\title{
The Impact of International Financial Reporting Standards Adoption and Banking Reforms on Earnings Management: Evidence from Nigerian Banks
}

\author{
Matthias Nnadi \\ School of Management, \\ Cranfield University, UK
}

\section{Obiamaka A. Nwobu}

Department of Accounting, Covenant University, Nigeria

\begin{abstract}
This study examines stock market reaction and the impact of IFRS adoption on the Nigerian stock market. The paper also evaluates the effect of the Central Bank of Nigeria (CBN) reforms on earnings management of Nigerian banks. The result indicates no evidence of any significant effect on the market but a negative stock reaction in the medium term. Our finding highlights mixed impact of IFRS adoption on earnings management; but a significant decrease in earnings management in the post CBN reforms. Our study shows that adoption of IFRS was wrongly timed in Nigeria as the fragile investors' sentiment which was just recovering from the shock of the global financial crisis could have been weakened by the negative market returns. These results have signal effect on investors.
\end{abstract}

Keywords: earning management; reforms; bank; IFRS; adoption; Nigeria

African J. Accounting, Auditing and Finance, Vol. X, No. Y, pp.000-000. 


\section{Introduction}

In response to the financial irregularities in some Nigerian banks following the 2007-2008 global financial crises, the central bank of Nigeria (CBN) between 2009 and 2012 introduced several banking reforms to enhance the quality of information provided by banks. These reforms were aimed at tackling poor quality financial reporting, and in order to restore confidence in the system (Lamido, 2012). The reforms coincided with IFRS adoption in which the Nigerian authorities mandated all listed companies including banks and significant public interest entities to adopt IFRS effective from $1^{\text {st }}$ January 2012. Hence this paper investigates the joint impact of the banking reforms and IFRS adoption on earnings management of Nigerian banks.

Most studies on the impact of mandatory IFRS adoption have focussed on developed economies and countries such as the EU member states, the G-20 member countries, or the emerging economies like Brazil with little attention paid to examining its impact in developing countries (Daske et al, 2008; Chen et al, 2014; Armstrong et al, 2010). And to the best of our knowledge, no studies have examined the effect of both the IFRS adoption and bank reforms concurrently on the management of bank earnings. Although, Green and Reinstein (2004) examine bank reform, their study focuses primarily on the effect of such reforms on fraudulent practices. This paper therefore fills two gaps. First, it examines the impact of IFRS adoption on bank stocks of a developing country. Second, we evaluate the impact of bank reforms following IFRS adoption on earnings management of listed banks in Nigeria. We use Nigeria as a test case as it is considered Africa's largest growing economy (The Economist, 2014). 
Our study investigates the market's reaction to mandatory IFRS adoption. The paper provides empirical evidence of IFRS impact on the Nigerian financial market. By so doing, we hope to provide to the policymakers, a basis for evaluating the success of the policy. Jim'enez and Saurina (2006) emphasise the importance of prudent accounting system particularly in the face of the overwhelming evidence of earnings management in the banking sector (Gombola, et al, (2016; Akinobu and Iwasaki, 2015); as well as robust prudential guidelines required by the IFRS. Banking reforms therefore become the best option of instilling any significant prudential behaviour through accounting rules. The effectiveness of such reforms has not being empirically examined in the banking studies. Thus this study provides a lead towards such evaluations particularly in developing economies.

Our findings indicate that the stock market did not react immediately following the announcement that IFRS would be mandatorily adoptedby the banks, and that that earnings management decreased with the Central Bank of Nigeria reforms. These results present an interesting perspective different from those argued in previous studies. The rest of the paper is structured as follows. Section 2 reviews the extant literature and formulates our hypotheses. In section 3, we describe the data source while section 4 is the research method and regression model. In section 5, we present the results and an accompanying discussion while section 6 concludes the study and makes suggestions for future research.

\section{Literature review and hypotheses development}

Our study is underpinned by the signalling hypothesis. Based on signalling theory, corporate disclosures usually signals companies' performance to shareholders; we argue that the IFRS adoption serves as a signal to investors on the credibility of financial reports. Corporate and economic theories suggest that disclosure plays an important information role in market 
based economics (Healy and Palepu, 2001), and that increased disclosure levels can reduce information asymmetries between the firms and investors (Verrecchia, 2001). Most empirical studies examining the benefits of IFRS claim that increased disclosures have mixed results and typically focus on capital market effects and earnings management (Laia et al, 2014). Our study extends prior research on the IFRS on management of earnings by investigating the impact of the mandatory IFRS adoption during a period of bank reforms in Nigeria.

Applying the signalling hypothesis to our empirical setting, we argue that IFRS adoption increases the disclosure level of a firm by allowing outside capital providers to have more information to evaluate the return of investment opportunities. Previous studies opine that increased disclosures reduce the information advantage of managers, and hence increase market liquidity and reduction in cost of capital (Easley and O'Hara, 2004).

Although accounting statements are prone to manipulation, however the conjecture is that informed investors can still infer some useful information about the value of the firm. Value relevance studies in financial accounting assess how accounting information is used by investors in equity valuation. Thus, a combination of IFRS adoption and bank reforms signal a high level of credibility on the financial information provided to investors. As earlier noted, the IFRS is characterised by high quality of earnings and extensive disclosure relative to the domestic accounting standards (Moscariello et al, 2014; Armstrong et al, 2010). Therefore, the mandatory adoption of IFRS and the consequent bank reforms by the central banks will provide a signal that new financial information provided are credible and relevant to investors.

A remarkable challenge in the adoption of the IFRS in Nigeria is that the infrastructure supporting the financial reporting system such as the auditors, analysts, accountants have developed around the Nigerian Statement of Accounting Standards, and not with the IFRS. 
As Madawaki (2016) observes that the shortage of these accounting professionals adds to the obstacles of effective implementation of the IFRS. In addition, major changes to the financial reporting framework are required for the convergence. The Nigerian financial regulations such as the Companies and Allied Matters Acts, Securities and Exchange Commission, Central Bank of Nigeria Act, Bank and Other Financial Institution Act, Companies Income Tax Act and Federal Inland Revenue Service Act were enacted prior to the emergence of IFRS and would thus require some amendment to comply with IFRS guidelines.

Adopting IFRS without fully implementing it does not bring about the full benefits of increase from the information environment. Countries with stronger legal systems and enforcement mechanisms for implementing the standards benefit more from adopting IFRS than other countries with weaker legal systems (Pope and McLeay, 2011; Soderstorm and Sun, 2007). Since these national barriers or boundaries cannot be erased overnight, differences in accounting quality may persist into the future.

Rationalising these findings in literature, it could be logically inferred that the mandatory adoption of IFRS in Nigeria would attract positive investor reaction. It would bring about cross-country comparability of financial statements which in turn could increase the confidence of foreign investors. Thus, it is on this premise that the following hypothesis is developed:

H1: The mandatory adoption of IFRS in Nigeria will attract positive investors' reaction.

\section{IFRS adoption in Nigeria and earnings management}

The goal of the IASB in propagating IFRS is to develop an internationally acceptable set of high quality financial reporting standards. Studies examining the impact of IFRS adoption in Nigeria have focused mainly on the stock market reactions and value relevance following the 
announcement and adoption of the standards (Umoren and Enang, 2015; Okoye et al., 2014; Ajao and Wemambu, 2012). These studies provide evidence that the adoption of the Standards enhanced the credibility of the financial statements. Okpala (2014) examines the role of IFRS adoption in attracting foreign direct investments (FDI) in Nigeria and argues that the significant growth in FDI is attributable to the adoption of IFRS by the country.

According to Madawaki (2016), the adoption of IFRS in Nigeria was planned into three phases: the first was for publicly listed entities and significant public interest entities to prepare their financial statements using applicable IFRS by January $1^{\text {st }}$ 2012. The entities were required to convert their closing balances at December 2010 to IFRS-based figures which would serve as the opening balance sheet figure for January 2011. Thus the full IFRS compliant financial statements were to take off starting December 31, 2012 with 2011 as comparative year.

The phase requires public interest entities to mandatorily adopt IFRS for statutory purposes by January 1, 2013. This implies that all other public interest entities in Nigeria were statutorily required to issue IFRS based financial statements for the year ended December 31, 2013. The third phase was for the adoption of IFRS for Small and Medium Enterprises (SMEs) by the end of December 31, 2014. The entities that do not meet the IFRS for SMEs criteria were to report using the Small and Medium-sized Entities Guidelines on Accounting (SMEGA).

The adoption of the IFRS has significant implication and effect on taxation in Nigeria. Madawaki (2016) notes that the adoption of the Standards implies that the audited accounts to be submitted to the Federal Inland Revenue Service (FIRS) would be prepared in compliance with the standards issued by the International Accounting Standards Board (IASB). He notes that there are differences between the Nigerian Accounting Standards and the IASB which 
results from the conversion to IFRS particularly in area of taxation. For instance, the Nigerian Statement of Accounting Standard 19 (Accounting for taxes) allows for extra ordinary items in the computation of tax liability which is not acceptable in IFRS 12 (Income and Taxes). Such differences can results in significant variations in earnings of firms using each standard regime.

Whilst it may still be unresolved in literature what the full impact IFRS has on earnings management, evidence points that its long-term impact will likely lead to reduced earnings management. Sharp earnings management practices were observed in some Nigerian banks following the global financial crisis (Lamido, 2010). This made the CBN to introduce sweeping banking reforms (among them IFRS adoption) between 2009 and 2012. It is expected that the mandatory adoption of IFRS would help reduce the level of earnings management. Taylor and $\mathrm{Xu}$ (2015) demonstrate that firms identified as conducting real earnings management activities do not experience a significant decline in subsequent operating performance. Thus, the second hypothesis states as:

H2: The mandatory adoption of IFRS reduced earnings management in Nigerian banks.

This hypothesis is consistent with the line of thought that the mandatory adoption of IFRS in Nigeria will cause Nigerian banks to make more detailed disclosures of their true financial position and this will subject them to more scrutiny and decrease their incentive to 'manage' their books. This argument is built on the premise that IFRS has a higher disclosure quality than Nigeria's local accounting standards, otherwise the Nigerian authorities will not have any incentive to advocate its adoption if it does not improve their accounting quality. 


\section{Impact of banking reforms on earnings management}

The banking reforms which took place in Nigeria from 2009 to 2012 were initiated to enhance the quality of banks, establish financial stability, enable healthy financial sector evolution and ensure the financial sector contributes to the real economy (Lamido, 2010). The Nigerian banking system was at the brink of collapse following the global financial crisis. There were inadequate disclosure and transparency of banks' financial position, critical gaps in regulatory frameworks and enforcement, poor corporate governance and uneven supervision and enforcement. Therefore, exhaustive measures were needed to forestall impending collapse of the system.

Responding to the threat of collapse, the CBN injected six hundred and twenty billion naira (equivalent of US $\$ 41,333,333,333$ ) into the banking system and replaced the management of eight Nigerian banks. Other measures adopted include strengthening the corporate governance in banks to ensure they abide by international best standards, setting up an internal risk management initiative based on the ICAAP (UK) and COSO (US) frameworks in order to develop Nigerian capital adequacy and enterprise risk assessment process, establishing an examination committee to partner the Nigerian Accounting Standards Board in making sure that banks adhere to the Nigerian GAAP and IFRS (Lamido, 2012). The banks were saved, although some of them did not retain their previous corporate structure. For example Access bank merged with Intercontinental bank into a standalone Access bank following the reform. The bone of contention is whether these reform measures adopted had the desired impact on earnings management.

Following the 'dot.com' bubble burst in the early 2000s, which exposed the endemic misrepresentation of the true financial position of some US corporations; US legislators enacted the Sarbanes-Oxley Act of 2002 which sought to improve the accuracy and reliability 
of financial information presented by organisations. Researchers investigated the immediate impact of these reform and found that earnings management decreased consistent with investor expectation ( $\mathrm{Li}$ et al., 2008) and firms reported lower discretionary accruals after the act was enacted than in the period before the Act (Lobo and Zhou, 2006). Such incidence are not surprising as Ewert and Wagenhofer (2012) show the existence of a subtle interactions between accounting standards, the institutional environment, and earnings management. Stocken (2013) suggests that a firm's disclosure policy depends on the features of its environment.

Just like the Sarbanes-Oxley reform, it is debatable as to whether the Nigerian banking reforms is sustainable though in the short to medium term reforms usually achieve their intended objective. This could partly be due to the public apathy towards infringing companies, consequently firms keen on maintaining a good corporate image would try to avoid a public backlash.

Drawing inference from the findings observed in the US it is plausible to expect that the banking reforms embarked upon by the Nigerian authorities would have positive impact on Nigeria's banks. Based on this premise, the third hypothesis is expressed as:

H3: Banking sector reforms reduced earnings management in Nigerian Banks.

\section{Data}

Our sample comprises of all commercial banks currently operating in Nigeria as at December 2013 and listed on the Nigerian stock exchange. Only listed banks are considered since they are publicly traded. It is assumed that the stock market is efficient and investors rational (a 
necessary condition), otherwise changes in a firm's stock price or stock traded volume cannot be used as a proxy for market reaction.

The 2005 banking consolidation reform which raised the minimum capital requirement of banks from $\mathrm{N} 2$ billion to $\mathrm{N} 25$ billion caused the number of commercial banks operating in Nigeria to decrease from 89 to 24 . Banks that could not independently meet the new capital reserve merged to satisfy the requirement. Following the recent banking reform, four ailing banks (Intercontinental Bank, Oceanic Bank, Fin Bank and Equitorial Trust Bank) lost their operating license, and were delisted from the stock exchange. Their assets and liabilities were immediately acquired by surviving banks (an arrangement fostered by the $\mathrm{CBN}$ ) in order to forestall panic or bank run in the sector.

Three other banks who received capital injection from the CBN namely Spring bank, Bank PHB and AfriBank are wholly owned by the Asset Management Company of Nigeria (AMCON), a state-owned entity created to resolve the issue of non-performing loans in Nigeria's banking sector, were re-launched (rebranded) as Enterprise Bank limited, Keystone Bank limited and Mainstreet Bank limited respectively in order to give them a new corporate identity. These state owned banks are no longer listed on the stock exchange; hence they are excluded from the sample. Two of the commercial banks operating in Nigeria, Standards Chartered bank and Citi bank are subsidiaries of foreign banks and are not listed on the Nigerian Stock Exchange; for this reason they are also excluded. Our final sample therefore is 15 commercial banks.

\section{Methodology and regression model}

\section{a. Examining market's reaction to IFRS adoption}

Similar to Armstrong et al., (2010) stock market return is adopted as proxy for measuring investors' reaction. It is expected that investors will react positively to news that a firm 
voluntarily adopts IFRS, or when it is mandated and complies to do so. Consequently it is expected that the stock market return of IFRS adopters will be significantly different from that of the index during the adoption period. Variable RETURN is used as proxy to measure market reaction and it is calculated as the difference between the three quarter stock return of IFRS adopters and the three-quarter return of the Nigerian Stock Index over the same period. The period of the stock return observed is one quarter before and after the firm publishes its first IFRS compliant statement. This three-quarter window is used to ensure the return obtained is not due to spurious market volatility. It is assumed that RETURN captures the abnormal market return attributable to IFRS adoption. It is also assumed that no other significant event or news took place during the event window that might bias or confound the return.

Three scenarios to which investors are likely to respond to are identified. They are:

1. When the Nigerian authorities announced in July 2010 that banks are to mandatorily adopt IFRS.

2. When the banks actually adopts IFRS.

3. And the period after the banks produced their first full year IFRS compliant statement.

These scenarios (events) are examined separately using event study methodology. As noted previously, four banks had already voluntarily adopted IFRS even before the Nigerian authorities announced that the standards will be mandatorily implemented; hence they are excluded from the sample for event 1 study. For the test to be unbiased it is assumed that investors respond quickly and rationally to these events and that the market is efficient. These assumptions are necessary because if investors do not respond quick enough or rationally during the event window, any changes in stock return recorded during the period could be attributed to chance. Where there are significant frictions in the market that could impair 
investors' responsiveness to changes in the information environment, then the window of observation may not be large enough to capture the full reaction.

To test the market's reaction to event 2 , the study examines the period when the banks actually adopt IFRS regardless of whether the firm is an early adopter or late adopter. There has been two accounting year-end since IFRS was mandatorily enforced; this provides an opportunity to test the short to medium run investors' reaction to the enforcement (event 3). The event model design is similar toFama and French (1993) which suggest that overall market factors, firm size and book to market equity are the main risk factors that affect stock return. The model used for the event study is given as:

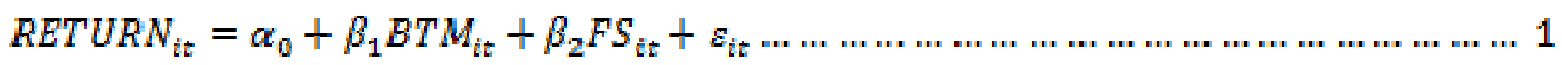

(See appendix for definition of variables).

Model 1 is appropriate for testing events 1 and 2 since in the short term the impact of changes in macroeconomic variables may not be fully transmitted into the stock market so the excess abnormal return observed is only due to investor's reaction to the event. It is important to note that this has nothing to do with frictions or inefficiency of the stock market but with the several stages it takes before the benefit of a policy action is felt by firms. For example if the Central Bank announces cut in interest rate, the firm's cost of debt does not immediately reflect this change and their existing obligations may not be affected if they were fixed when the contract was entered. The benefit will be felt in future contracts. It is expected that model will generate a statistically significant result and that BTM and FS capture the cross-sectional variation of returns of the stocks. 
In order to extend the model to be applicable for studying event 3 , some observations and assumptions are necessary. The US Federal Reserve began cutting down its monthly assets purchases in 2013 and stock markets around the world, particularly in emerging and developing countries, experienced significant capital outflow. Nigeria's stock exchange was not immune to the fallout. Its all-share index declined significantly, although it has since rebounded, exchange rate also depreciated. These shocks are likely to have affected all stocks listed on the exchange.

For simplicity it is assumed that these shocks will impact all stocks of all listed banks in Nigerian stock exchange in the same manner and to the same extent. This assumption is necessary because it makes it less complicated to isolate the impact of each shock on each stock. If all stocks are affected by shocks in the same manner and to the same extent then subtracting the index's return from a firms' stock return would ensure that the residual return are firm specific. Based on this assumption, model 1 can now be used to estimate event 3 . The frequency of data for stock return and corresponding index return along with other variables in model 1 are weekly instead of the quarterly as used for event 1 and 2 . This is because for event 3 , the aim is to access investor's reaction over a relatively long period (2 years) and not over a critical period, hence the need for more observations.

\section{b. Measuring IFRS impact on Earnings management}

Two metrics are used to assess the impact of IFRS adoption on earnings management in Nigerian banks. Dechow et al. (1995) provide a good overview of several methods of examining earnings management. One of the most common proxies used for measuring earnings management is discretionary accruals. Accruals are the part of the revenue and expenses that do not involve collections and payments so do not reflect on the cash flows 
hence making it vulnerable for manipulation. It is calculated as the difference between profit and operating cash flows.

However, owing to the specific accounting requirement which financial institutions are required to meet, the Jones model cannot be used in this study. Industrial and commercial companies treat debt and leverage differently from banks and this will affect how items on their financial statements are interpreted.

To ensure comparability between this study and that of prior studies, a pooled estimation model similar to that used in Barth et al., (2008), Ahmed et al., (2013); Capkun et al., (2012). and Christensen et al., (2015) is adopted. The first metric used in assessing the earnings management in the sample focuses on examining the variability of the change in net income scaled by total assets $(\Delta \mathrm{NI})$. The variances of the residuals of the regression of $\Delta \mathrm{NI}$ on variables identified in prior literature to have an influence on changes in earnings are included $^{1}$. The model along with the description of its variables is shown below. See appendix for definition of the variables.

$$
\begin{aligned}
& \Delta N I_{i t}=\alpha_{0}+\beta_{1} S I Z E_{i t}+\beta_{2} \text { GROWTH } H_{i t}+\beta_{3} E I S S U E_{i t}+\beta_{4} L E V_{i t}+\beta_{\mathrm{s}} \text { DISSUE }_{i t} \\
& +\beta_{6} T_{U R N_{i t}}+\beta_{7} C F_{i t}+\beta_{g} A U D_{i t}+\beta_{9} N U M E X_{i t}+\beta_{10} X L I S T_{i t} \\
& +\beta_{11} C L O S E_{i t}
\end{aligned}
$$

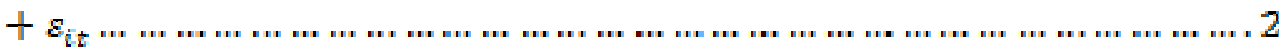

The dataset used is partitioned into two samples; early IFRS adopters and late IFRS adopters. This distinction is made to test whether early IFRS adopters showed significantly different earnings management behaviour from late IFRS adopters. For each of the sample it is investigated whether the variance of the residual obtained using model 2 differed

${ }^{1}$ See Ashabaugh, (2001); Pagano et al., (2002), Lang et al., (2003), Tarca (2004) and Lang et al., (2006) for evidence supporting the inclusion of these variables in the model. 
significantly from pre and post IFRS adoption. Obtaining a smaller statistically significant variance in the residual post IFRS adoption will suggest evidence of earnings management.

Our second metric for assessing earnings management examines the mean ratio of the variability of the change in net income, $\Delta \mathrm{NI}$ to the variability of the change in operating cash flows $\Delta \mathrm{CF}$. This second metric is needed as a confirmatory proxy because the first metric did not account for the volatility of cash flows. Barth et al., (2008) argue that firms with more volatile cash flow normally have more volatile net income. A firm with volatile cash flow might also have volatile net income but this is not sufficient evidence to suggest that they engage in earnings management.

Owing to the intensive scrutiny banks face from several regulatory bodies, bank managers are less likely to manipulate their cash flows in order to smooth their earnings. Accruals then become the likely item that can be used to manipulate earnings. Barth et al., (2008) suggest that if firms use accruals to manage earnings, then the variability of the change in net income should be lower than that of operating cash flow. This is because the volatility of net income will no longer track that of operating cash flows. Change in cash flows $\Delta \mathrm{CF}$ is modelled as:

$$
\begin{aligned}
& \Delta C F_{i t}=\alpha_{0}+\beta_{1} S I Z E_{i t}+\beta_{2} \text { GROWT H } H_{i t}+\beta_{3} \text { EISSUE }_{i t}+\beta_{4} L E V_{i t}+\beta_{5} D_{I S S U E_{i t}} \\
& +\beta_{6} T U R N_{i t}+\beta_{7} C F_{i t}+\beta_{8} A U D_{i t}+\beta_{9} N U M E X_{i t}+\beta_{10} X L I S T_{i t} \\
& +\beta_{11} C L O S E_{i t}
\end{aligned}
$$

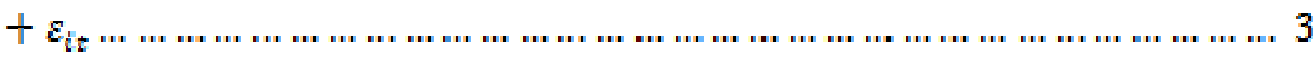

Model 3 is similar to model 2 except for the dependent variable. This is because as opined by Barth et al., (2008) $\triangle \mathrm{CF}$ is also likely to be sensitive to variety of factors un-attributable to the financial system just like $\Delta \mathrm{NI}$. The variability of $\Delta \mathrm{CF}$ is studied by examining the variance of the residuals generated by the model 3 pre and post IFRS adoption. The analysis is performed on the two subsets of the data: early IFRS adopters and late IFRS adopters. For 
each sample the ratio of the variability of $\Delta \mathrm{NI}$ to variability of $\Delta \mathrm{CF}$ is calculated. A smaller ratio will suggest the presence of earnings management.

\section{c. Impact of banking reform on earnings management}

We test whether the banking reforms introduced by the CBN had a significant impact on earnings management in Nigerian banks. One of the anomalies that triggered the CBN's intervention was that some banks were still recording non-performing loans as assets on their books, instead of writing off, thereby manipulating their earnings. The intervention compelled banks to write off bad debts or at least make provision for it as soon as they become aware that the debtor can or is no longer able to meet his obligations.

We use panel data and applied the modified of Leventis et al., (2011) and Ahmed et al., (1999) models to test whether this form of earnings management has reduced following CBN's intervention and IFRS adoption. The loan loss provision banks make on their income statement is used as proxy for earnings management. The ensuing model along with the description of its variables is as in Model 4:

$$
\begin{aligned}
& L L P R_{i t}=\alpha_{0}+\beta_{1} E B T_{i t}+\beta_{2} \text { IFRS }_{i t}+\beta_{3} \text { REFORM }_{i t}+\beta_{4} R E F O R M * E B T_{i t} \\
& +\beta_{5} I F R S=R E F O R M=E B T_{i t}+\beta_{6} L n T A_{i t}+\beta_{7} C F E E R_{i t}+\beta_{8} \Delta G D P_{i t}
\end{aligned}
$$

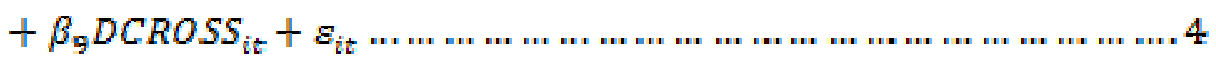

(See appendix for definition of the variables).

A dummy variable IFRS is introduced to control for the impact of the mandatory IFRS adoption. As noted previously, the banking reforms occurred simultaneously with IFRS adoption hence the need to control for its impact. It is expected that due to the higher 
disclosure quality owing to IFRS adoption, earnings management will decrease. The ratio of loan loss provision to total loans (LLPR) is used instead of the face value of the provision to ensure that proxy is comparable among banks regardless of their size. Larger banks are more likely to issue more loans than smaller banks hence their loan loss provision may be higher than those of smaller banks in absolute terms but not necessarily so proportionally.

The ratio of earnings before taxes and loan loss provisions to total assets (EBT) is used as proxy for measuring earnings management. This metric is chosen because it accounts for the influence of LLPs for which evidence from Anadarajan et al., $(2003,2007)$ and Perez et al., (2008) suggest that bank managers use it as a tool for aggressive earnings management. Bank managers are likely to raise their LLPs in periods of high operating income to reduce the volatility of their earnings. [See for example Perez et al., (2008); Anadarajan et al., (2007); and Lang et al., (2006)].

Another dummy variable REFORM was introduced to capture the impact of the banking reform. The banking reform occurred from 2009 to 2012 but most of its impact was felt from 2011 onwards, hence 2011 is chosen as a cut-off. REFORM takes a value of 1 for observations that occurs from 2011 onwards or else 0. An interaction variable REFORM*EBT was introduced to test for the use of loan loss provision as a earnings management technique for both the pre and post CBN intervention. It is expected that earnings management among banks will decrease post CBN intervention.

Consequently if banks managers were to use loan loss provisions for earnings management purposes, it is expected that EBT will have a positive coefficient (Leventis et al., 2010). It is expected that the coefficient of the interaction term REFORM*EBT will be smaller post banking reform. A second interaction term that attempts to capture the interaction between IFRS adoption, banking reform and earnings management (IFRS*REFORM*EBT) is 
introduced in the model to capture banks who still manage their earnings post banking reform; hence it is likely to be positive and significant.

\section{Result and discussion}

\section{Descriptive results}

Tables 1, 2and 3present the list, net income and descriptive statistics of the remaining 15 banks that meet the sampling criteria and used in the study.

\section{[Insert Table 1here]}

All relevant accounting information used in the study was obtained from the respective bank's published statement and from Bloomberg, a global financial resource database. Bloomberg was the primary source of the data as it ensures that the information obtained is comparable and consistent. Annual reports were only used when the required information was not available on Bloomberg. Owing to the non-uniform availability of data, the number of observations varied across banks. Prior to 2009 Nigerian banks independently had their own accounting year end. This occurrence ended in 2009 following a harmonization brokered by the Central Bank between the banks and other financial institutions. December $31^{\text {st }}$ was adopted as the accounting year-end for all financial institutions operating in Nigeria effective from 2009. The total assets of the banks range from USD 24, 158 million to USD 2,132 million and a market capitalisation of USD 5, 445 million to USD 120 million. First Bank of Nigeria PLC is the largest (by total assets) with assets of $\$ 24,158$ million and the smallest bank is Wema Bank PLC with total assets of \$2, 132 million. However, Guaranty Trust Bank PLC has the highest market capitalisation of $\$ 5,445$ million. However, Zenith Bank PLC is the most profitable by net income of $\$ 614$ million followed by Guaranty Trust Bank PLC of 
$\$ 580$ million, and the least profitability bank is Wema Bank PLC with a net income of $\$ 13$ million.

The mandatory IFRS adoption date was 2012 accounting year-end but four banks; Guaranty Trust bank, Access bank, First bank and United Bank of Africa adopted the standards at least 3 years before the enforcement date. Consequently these banks are referred to as Early Adopters while remaining banks are referred to as Late Adopters. Early adopters might have an incentive for adopting the standards early on. Adopting the standards before their peers could serve as a signal to foreign investors that they abide by global best practices and have good corporate governance. It is then anticipated that early adopters will likely attract a larger positive investor reaction and would show less signs of earnings management than late adopters.

The mean of the net income (0.010), cash flows (0.054), cash flows $(0.163)$, change in liabilities (0.402) and common stock (0.741) of pre-adopters is higher than their post IFRS adoption statements. These suggest that the adoption of the standards scaled down figures that otherwise make the financial statements look different than normal. The decrease in the net income of the banks in their post IFRS explains the impact of the adoption in reducing the management of earnings. Table 2 shows that there is no change in the net income of the late adopters even after adoption. This suggests that this category of banks were less susceptible to earning management. However, the level of loan loss provision of late adopters reduced from 0.157 to 0.124 indicating that the CBN reforms together with the IFRS adoption have effective impact in the classification of loan losses.

\section{[Insert Tables 2 and 3 here]}




\section{Market reaction: Announcement period}

Table 4 presents empirical results of the investigation into markets immediate reaction to the announcement of a proposal for Nigerian banks to mandatorily adopt IFRS. Joos and Leung (2013) and Armstrong et al (2010) document evidence of positive investors' reaction to IFRS adoption. This is because adopting IFRS leads to an improvement to the information environment. However, our result finds no statistical significant evidence of a positive investor reaction to IFRS adoption in Nigeria.

The result represents a deviation from the theoretically predicted outcome. Several factors could have been responsible for the deviation of the result from the hypothesised prediction. The model only had 10 observations and this is a relatively small sample size. The research design restricts the number of observation that could be allowed in the sample. Only currently listed banks could be included in the sample. This criterion precludes some banks that were operational when the announcement was made but have since been delisted from the stock exchange or acquired by other banks. This raises the prospect that the model may suffer from survivorship bias.

\section{[Insert Tables 4]}

The likely explanation to our result is based on efficient market hypothesis (we assumed it holds). Taking into account the frictions in the market, assuming the market is semi-strong form efficient. There has been speculation in the market that banks will be made to adopt stricter measures in response to the fallout from the global financial crisis. Some of the top performing banks like GT bank and First bank had already adopted IFRS, so it was only a matter of time before the regulators made it compulsory for all other banks. Also multinational banks like HSBC and Commerz banks were already requiring their local partners to adopt IFRS in order to ensure long term partnership. This information was public 
and since the market is semi-strong form efficient, it would have priced this anticipated enforcement into the price of stocks, hence the reason why there was no noticeable market reaction.

The implication of this finding is either the Nigerian stock exchange is fairly efficient and stock prices reflects publicly available information, or that investors were actually waiting for the announcement to be enforced before they react. Weak enforcement standards in developing countries might have delayed market reaction to policy announcements.

\section{Market reaction: Adoption period}

Table 5 present results showing markets reaction during the adoption period. The model's result indicates that the abnormal market return $(\alpha)$ is significant at $95 \%$ confidence level. The result reveals that the market reacted more negatively to IFRS adoption in larger banks. A firm that is $1 \%$ larger than the market average generates $0.113 \%$ less return than the market return.

\section{[Insert Table 5 here]}

Our result corroborates previous findings (Bruggeman et al., 2011) that investors react to IFRS adoption, but challenges Joos and Leung (2013) and Armstrong et al (2010) evidence of positive investor reaction. It can be deduced that the adoption of IFRS attract market reaction because it improves the information environment (asymmetry) in the market. The markets negative reaction suggests that the increased information made public certain previously private negative information that were not originally priced, hence justifying foreign investors scepticism of local firms who adhere to only local standards. 
Whilst this finding presents a unique perspective, it is important to understand the context surrounding the adoption period. Majority of the banks adopted IFRS in 2012 and this represents the period when banks were making adjustments owing to the reforms introduced by the $\mathrm{CBN}$ to reposition Nigerian banking sector. The near collapse of the banking sector as a result of the global financial crisis had already weakened investor sentiment (local and foreign alike), so any further discovery of inadequacy in the bank books will likely trigger a significant negative reaction. One likely inference that could be drawn from this finding is that Nigerianlocal accounting standardshas a lower disclosure quality than IFRS; adopting IFRS increased the information environment of the investors.

From a policy perspective, we posit that mandating the adoption of IFRS was wrongly timed. The immediate negative returns could have further weakened the fragile investors' sentiment which was just recovering from the shock of the global financial crisis. If this sentiment was transmitted to the real economy, it might have triggered a full scale collapse of the banking system. The counter argument is that by ensuring that Nigerian banks adhere to global best practises (even though it is not certain that it would forestall future crisis), the Nigerian authorities have signalled to the investing public that they are willing to and are doing everything possible to address the anomalies in Nigerian banks.

\section{Market reaction: Post IFRS Adoption}

Table 6 presents results showing market's reaction since the mandatory adoption of IFRS by Nigerian banks. The result indicates that the book market equity is significant suggesting that following the mandatory adoption of IFRS, the returns of banks have been significantly lower than those of the market index. This suggests that the short term negative investors' reaction observed continued into the medium term, although its impact is a lot weaker. 


\section{[Insert Table 6 here]}

The findings indicate that the market reacted more negatively to IFRS adoption in firms with higher book to market equity. Generally firms with higher book to market equity are firms whom the market do not anticipate any significant event or opportunity that would boost its future earnings potential. They can also be firms who the market suspects have an underlying structural or operational problem, hence their stock price signals investors negative sentiment about the firm and this reflects on their market value. Given that during this period many Nigerian banks recovered from the financial crisis and re-strategise their operation, it is rational for the market to react negatively to firms that have not made this transformational signal.

Our model result corroborates thesignal hypothesis that a firm's stock price is a signal of its intrinsic value. This explains why the model finds negative relationship post IFRS adoption for firms with higher book to market ratio.

The finding suggests some that evidence the Nigerian stock exchange is fairly efficient. Overall it is seen that the mandatory adoption of IFRS in Nigeria attracted investors reaction, this reaction even though negative suggest an improvement in the information environment due to the higher disclosure requirement of IFRS relative to Nigeria's local standards. The market reaction was larger in the short term, as expected, and still persisted into the medium term, although its impact diminished. 


\section{Measuring the impact of IFRS adoption on earnings management}

Using changes in net income $(\Delta \mathrm{NI})$

Table 7 present results comparing the level of earnings management in Nigerian banks pre and post IFRS adoption. The sample was divided into two, early adopters and late adopters, to reflect the period in which the banks adopted IFRS. Analysis of the two samples yielded different result. For early adopters, result show that the variability of change in net income $(\triangle \mathrm{NI})$ was lower before IFRS adoption, whereas it was higher in late adopters. This finding could present an important insight behind the incentive that inspired firms to adopt IFRS before they were mandated.

\section{[Insert Table 7 here]}

The difference in the variability of net income before and after IFRS adoption suggests evidence of earnings management. The result indicates that earnings management was higher in early adopters before IFRS adoption. This finding challenges the signalling hypothesis earlier proposed that adopting IFRS was meant to signal to investors, foreign and local alike, that the bank abided by global best practises and this was meant to increase their competitive advantage in attracting foreign direct investment. Our result supports the evidence show that earnings management decreased after IFRS adoption, implying that it is likely influenced by IFRS adoption (Barth et al., 2008 and Zeghal et al., 2011).

For late adopters, the result finds evidence that the variability of $\Delta$ NI was higher before IFRS adoption. This suggests that earnings management increased in late adopters post IFRS adoption. This finding leans support to previous studious (Callao and Jarne, 2010 and Ahmed et al., 2013) of increased earnings management post IFRS adoption. 


\section{Using changes in Cash flow}

Table 8 presents the level of earnings management in early and late IFRS adopters in the periods before and after adoption. We use the ratio of the variability of change in Net income to the change in cash flow as a metric for measuring earnings management. Findings reveal that earnings management decreased in early adopters post adoption whereas it increased in late adopters post adoption.

\section{[Insert Table 8 here]}

The result shows that for early adopters, the variability of the ratio of change in net income to change in net cash flow was higher in the post adoption period than the pre adoption period, and this is consistent with our previous result, where a different metric was used.Hence, it confirms that even after accounting for other factors that might affect the banks' cash flows, earnings management decreased post IFRS adoption. Therefore it can be concluded that for early adopters, IFRS was most likely responsible for the decrease in earnings management. The higher disclosure requirement of IFRS relative to local accounting standards was likely responsible for the meant that band had fewer avenues to misrepresent their true and fair financial position.

For late adopters the result shows that the variability of the ratio of change in net income to change in cash flow was higher in pre IFRS adoption. This finding is also consistent with ourprior finding that earnings management increased post adoption for late adopters. Hence the previous finding cannot be dismissed as occurring due to chance. It is therefore important to understand the rationale behind this occurrence.

The migration from one accounting standards to another, particularly when they are mandated, usually subjects the firms' account to greater scrutiny at the early phase. Observers (analysts) are keen to identify any additional information they could obtain from the new 
statement to aid their view of the firm. It is on this note that firms, being mindful of the adverse reaction that might follow if the prospect of their firm does not match its previous sentiment, exploit all measures within the new standards to manage their earnings. This is likely to have happened with the late adopters of in this study. This argument is consistent with Iatridis and Rouvolis (2010) and Capkun et al., (2012) that owing to the high transaction cost and volatility of income statement during transition from one standard to another, firms engage in earnings management in order not to alarm investors. They showed that earnings management decreased in the subsequent years after the transition. Thus may delay publishing a fully IFRS compliant statements because of the sceptism about shareholders reaction to it.

\section{Impact of banking reforms on earnings management}

Table 9 presents the result from an investigation into the impact of the banking reform enacted by the CBN on earnings management of Nigerian Commercial banks. Findings indicate that earnings management decreased after the reforms were enacted, hence justifying CBN's intervention.

\section{[Insert Table 9 here]}

The model used for the investigation is a pooled OLS model. The coefficient of EBT is positive, as predicted, highlighting the presence of earnings management thus corroborating the findings of Anandarajan et al. $(2003,2007)$ and Perez et al. (2008), although it is not statistically significant at the $95 \%$ confidence level. The coefficient of the interaction term REFORM*EBT is negative and is weakly significant at the $90 \%$ confidence level hence indicating that earnings management decreased in the post reform period. This finding validates our hypothesis [H3] that $\mathrm{CBN}$ reform decreased earnings management in Nigerian 
banks. Even if some of the variables particularly the IFRS term which have been shown previously to decrease earnings management are not statistically significant, it merely represents that their influence on the dependent variable is not as strong as predicted.

While this finding have been interpreted as evidence of use of LLPs for earnings management purposes and subsequent decline in earnings management post $\mathrm{CBN}$ reform, an alternative explanation based on cross subsidization and corporate governance is possible. In years of high operating income, bank managers are likely to increase their LLPs more than the stated requirement in the accounting standards. During downturn, they are likely to return back this excess provision to augment drop in earnings thus using LLPs as strategic reserve. It can be argued to be a prudent risk management measure (Leventis et al., 2011). However owing to the asymmetric information between banks managers and regulatory authorities; it is not possible to truly tell the primary motive behind such actions. Overall the findings are indicative of a decrease in earnings management after the CBN enacted its reforms. However since the result is weakly significant, the decrease in earnings management cannot be fully attributed to the CBN's intervention.

\section{Sensitivity analysis}

To ensure the robustness of the results obtained, sensitivity tests with respect to the methodology are carried out to validate the interpretation of the findings. To control for heteroscedasticity that may occur in model 1 , robust standards errors are used to re-estimate events 1, 2 and 3. Findings indicate that results did not change qualitatively, hence the results in table 3, 4 and 5 are robust and their interpretations are significant. 
Model 2 and 3 were originally estimated using Pooled OLS regression. Therefore, there is chance that the $t$ statistic could be over stated. To control for this, the models are re-estimated using fixed effect and random effect panel regressions. The coefficients generated were qualitatively the same. Instead of comparing the variance in the residuals generated before and after IFRS adoption by observing their nominal values, the residuals were tested using the two sample variance test to study whether they are statistically different. The findings support the conclusion drawn for tables 6 and 7, hence the result are robust.

Similarly, Model 4 was also re-estimated using fixed effect and random effect panel regression to control for the possibility of the $t$-statistic generated previously being over stated. The finding confirms that results for model 4 in table 8 were not affected by the methodology.

\section{Conclusion}

This paper investigates how IFRS adoption and the subsequent reforms introduced by the Central bank of Nigeria (CBN) affected the level of earnings management in Nigerian banks. Some Nigerian banks had already adopted IFRS prior to it being made mandatory; this paper investigates whether they had any incentive to do so. Our finding supports the signalling hypothesis that adopting IFRS was meant to signal to investors, foreign and local alike, that the bank abided by global best practises and this was meant to increase their competitive advantage in attracting foreign direct investment.

To investigate the market's reaction, three events are identified: when the announcement was made that IFRS will be mandatorily enforced; when the banks actually adopt IFRS; and the post adoption period. These events are analysed by studying the excess return of bank's stock 
around the period each of these events occurred. Findings indicate no significant market reaction when the announcement was made, that the market reacted negatively when the banks adopted the Standards especially for larger banks, and that the market reacted more negatively to banks with high book to market ratio in the post adoption period. Implications of these findings are discussed.

Overall two metric are used to examine whether adopting IFRS reduced the level of earnings management in Nigerian banks. The result suggests that earnings management decreased post adoption for banks that adopted IFRS earlier on, whereas it increased for late adopters. However, it might be too early to draw a definite conclusion about the full impact adopting IFRS had on earnings management among Nigerian banks. Findings also suggest earnings management decreased post $\mathrm{CBN}$ reform.

This study contributes to the accounting literature by focusing on Nigeria, a developing country. Most prior studies have focussed on developed countries and emerging economies. It is common knowledge that the relatively higher frictions in developing markets makes it difficult to extrapolated results of research carried out on developed markets to make an inference on developing economies. This study fills this gap. Also since there have not been studies accessing the impact of IFRS adoption on Nigerian banks, this paper could form basis for evaluating the performance of the policy. The widespread adoption of IFRS means that many more developing countries are likely to adopt the standards. Regulators in these intending countries could be observing the benefits and implication of Nigeria's attempt at adopting the standards; hence this paper provides them with a good insight.

Whilst this study has made interesting findings about the impact of IFRS adoption on Nigeria, it should be viewed as an exploratory study; there are opportunities for future research. It is seen that investors reacted negatively to IFRS adoption in Nigeria in the short 
term, and the negative reaction continued into the medium term, although it was weaker. This might be early days to form a general view about the impact of the policy. Perhaps more post adoption observations are needed before making a definitive conclusion. Also, while exploring whether bank managers use loan loss provisions for earnings management purposes, other incentives, for example corporate control, were identified as being plausible reasons for the increase in loan loss provisions above the accounting requirement. Investigating these incentives could form basis for future study. 


\section{References}

Ahmed, A. S., Neel, M. and Wang, D. (2013), "Does mandatory adoption of IFRS improve accounting quality? Preliminary evidence", Contemporary Accounting Research, 30 (4), 1344-1372.

Ahmed ASC, Takeda C, Thomas S (1999) "Bank loan loss provisions: a re-examination of capital management, earnings management and signalling effects", Journal of Accounting \& Economics, 29, 1-25.

Ajao, M.G. and Wemambu, M.U. (2012) Volatility estimation and stock price prediction in the Nigerian stock market. International Journal of Financial Research, 3(1), 14-21.

Akinobu, S. and Iwasaki, T. (2015) The Effect of Institutional Factors on Discontinuities in Earnings Distribution: Public Versus Private Firms in Japan.Journal of Accounting, Auditing and Finance, 30 (3), 283-317.

Anandarajan, A., Hasan, I. and Lozano-Vivas, A. (2003), "The role of loan loss provisions in earnings management, capital management, and signaling: The Spanish experience", Advances in International Accounting, 16, 45-65.

Anandarajan, A., Hasan, I. and McCarthy, C. (2007), "Use of loan loss provisions for capital, earnings management and signalling by Australian banks", Accounting \& Finance, 47(3), 357-379.

Ashbaugh, H. (2001), "Non-US firms' accounting standards choices", Journal of Accounting and Public Policy, 20 (2), 129-153.

Bae, K., Tan, H. and Welker, M. (2008), "International GAAP differences: The impact on foreign analysts", The Accounting Review, 83(3), 593-628.

Barth, M. E., Landsman, W. R. and Lang, M. H. (2008), "International accounting standards and accounting quality", Journal of accounting research, 46 (3), 467-498.

Chen, C. J.P., Ding, Y. and Xu, B. (2014) The convergence of accounting standards and foreign direct investment. International Journal of Accounting, 49(1), 53-86. 
Callao, S. and Jarne, J. I. (2010), "Have IFRS affected earnings management in the European Union?",Accounting in Europe, 7 (2), 159-189.

Capkun, V., Collins, D. W. and Jeanjean, T. (2012), "Does adoption of IAS/IFRS deter earnings management", IFRS Deter Earnings Management.Available at https://tippie.uiowa.edu/accounting/phd/publications/collins_adoption.pdf. (Accessed 07/06/2016)

Christensen, H. B., Lee, D. E. and Walker, M. (2007), Incentives or Standards: What Determine Accounting Quality Changes Around IFRS Adoption? Manchester Business School.

Daske, H., L. Hail,L., Leuz, C. and Verdi, R. (2008) Mandatory IFRS reporting around the world: early evidence on the economic consequences, Journal of Accounting Research $46,1085-1142$.

Dechow, P. M., Sloan, R. G. and Sweeney, A. P. (1995), "Detecting earnings management", Accounting Review, 193-225.

Ewert, R. andWagenhofer, A. (2012), "Earnings Management, Conservatism, and Earnings Quality", Foundations and Trends ${ }^{\circledR}$ in Accounting: 6 (2), 65-186

Fama, E. F. and French, K. R. (1993), "Common risk factors in the returns on stocks and bonds", Journal of Financial Economics, 33 (1), 3-56.

Gombola, M.J., Ho, A. Y. andHuang, C. (2016)The effect of leverage and liquidity on earnings and capital management: Evidence from U.S. commercial banks. International Review of Economics \& Finance.43, 35-58.

Green, P.B. and Reinstein, B. (2004)Banking industry financial statement fraud and the effect of regulation enforcement and increased public scrutinyResearch in Accounting Regulation, 17, 87-106

Jim'enez, G. and Saurina, J. (2006) Credit Cycles, Credit Risk, andPrudentialRegulation. International Journal of Central Banking, 2 (2), 65-98

Jones, J. J. (1991), "Earnings management during import relief investigations", Journal of accounting research, 29(2), 193-228. 
Joos, P. P. and Leung, E. (2012), "Investor perceptions of potential IFRS adoption in the United States", The Accounting Review, 88 (2), 577-609.

Lamido, S. (2010), "The Nigerian Banking Industry: what went wrong and the way forward", Delivered at Annual Convocation Ceremony of Bayero University, Kano held on, $1^{\text {st }}$ March, 2010.

Lamido, S. (2012) "Banking reform and its impact on the Nigerian economy", Delivered at the University of Warwick Economic Summit, Warwick held on $17^{\text {th }}$ February 2012.

Lang, M., Raedy, J. S. and Yetman, M. H. (2003), "How representative are firms that are cross-listed in the United States?An analysis of accounting quality", Journal of Accounting Research, 41 (2), 363-386.

Lang, M., Smith Raedy, J. and Wilson, W. (2006), "Earnings management and cross listing: Are reconciled earnings comparable to US earnings?"Journal of Accounting and Economics, 42 (1), 255-283.

Leventis, S., Dimitropoulos, P. E. and Anandarajan, A. (2011), "Loan loss provisions, earnings management and capital management under IFRS: The case of EU commercial banks", Journal of Financial Services Research, 40( 1-2), 103-122.

Li, H., Pincus, M. and Rego, S. O. (2008), "Market reaction to events surrounding the Sarbanes-Oxley Act of 2002 and earnings management", Journal of Law and Economics, 51 (1), 111-134.

Lobo, G. J. and Zhou, J. (2006), "Did conservatism in financial reporting increase after the Sarbanes-Oxley Act?Initial evidence", Accounting Horizons, 20 (1), 57-73.

Madawaki, A. (2016) Adoption of international financial Reporting Standards and the changing accounting environment in Nigeria (in) Efobi, U., Nnadi, M. Tanna, S. and Iyoha, F. (eds.) Economics and Political Implications of International Financial Reporting Standards; Hershey PA, IGI publishers. 
Okpala, K.E. (2014) Adoption of IFRS and financial statements effects: the perceived implications of FDI and Nigerian economy. Australian Journal of Business and Management Research, 2(5), 76-83

Okoye, P.V.C., Okoye, J.F.N. and Ezejiofor, R.A. (2014) Impact of IFRS adoption on stock markets movement in Nigerian corporate organisation. International Journal of Academic Research in Business and Social Sciences, 4(9), 202-218

Pagano, M., Röell, A. A. and Zechner, J. (2002), "The geography of equity listing: why do companies list abroad?",The Journal of Finance, 57 (6), 2651-2694.

Perez, D., Salas-Fumas, V. and Saurina, J. (2008), "Earnings and capital management in alternative loan loss provision regulatory regimes", European Accounting Review, 17 (3), 423-445.

Pope, P. F. and McLeay, S. J. (2011), "The European IFRS experiment: Objectives, research challenges and some early evidence", Accounting and business research, 41 (3), 233266.

Soderstrom, N. S. and Sun, K. J. (2007), "IFRS adoption and accounting quality: a review", European Accounting Review, 16 (4), 675-702.

Stocken, P. C. (2013), "Strategic Accounting Disclosure", Foundations and Trends ${ }^{\circledR}$ in Accounting: 7 (4), 197-291.

Tarca, A. (2004), "International convergence of accounting practices: Choosing between IAS and US GAAP", Journal of International Financial Management \& Accounting, 15 (1), $60-91$.

Taylor, G.K. and Xu, R.Z. (2015) Consequences of real earnings management on subsequent operating performance. Research in Accounting Regulation, 22(2), 128-132.

The Economist (2014) How Nigeria's economy grew 89\% overnight.

Umoren, A. O. and Enang, E. R. (2015) IFRS adoption and value relevance of financial 
statements of Nigerian listed banks. International Journal of Finance and Accounting, $4(1), 1-7$.

Zéghal, D., Chtourou, S. and Sellami, Y. M. (2011), "An analysis of the effect of mandatory adoption of IAS/IFRS on earnings management", Journal of International Accounting, Auditing and Taxation, 20 (2), 61-72. 


\section{Appendix}

RETURN: difference between firm return and index return

BTM: book to market equity

FS: natural log of firm size

SIZE: The natural logarithm of end of year market value of equity;

GROWTH: percentage change in sales;

EISSUE: percentage change in common stock;

$\boldsymbol{L E} \boldsymbol{V}$ : end of year total liabilities divided by end of year equity book value;

DISSUE: percentage change in total liabilities;

TURN: sales divided by end of year total assets;

$\boldsymbol{C F}$ : annual net cash flow from operating activities divided by end of year total assets;

AUD: an indicator variable that equals (1) if the firm's auditor is PwC, KPMG, Deloitte, or E\&Y, and (0) otherwise;

NUMEX: the number of exchanges on which a firm's stock is listed;

XLIST: an indicator variable that equals one if the firm is listed on Nigerian stock exchange and Bloomberg indicates that the Nigerian exchange is not the firm's primary exchange;

CLOSE: the percentage of closely held shares of the firm as reported by Bloomberg

LLPR: Ratio of loan loss provisions (LLPs) to total loans

EBT: Ratio of earnings before taxes and LLPs to total assets

IFRS (Dummy variable): (1) if banks report under IFRSs, (0) otherwise

REFORM (Dummy variable): (1) if is observation is before 2011, (0) otherwise

REFORM*EBT: Interaction of banking reform with loan loss provision 
IFRS*REFORM*EBT: Interaction among IFRS adoption, REFORM and EBT

LnTA : Natural logarithm of total assets

CFEER: Ratio of commission and fee income to total assets

$\Delta$ GDP: Change in gross domestic product

DCROSS (Dummy variable) : (1) if banks are cross-listed, (0) otherwise

s:Error term

Table 1: summary description of Banks used in the study

\begin{tabular}{|l|l|l|l|}
\hline Bank Name & $\begin{array}{l}\text { Total Assets (mil } \\
\text { USD) for 2013 }\end{array}$ & $\begin{array}{l}\text { Current Market } \\
\text { Capitalisation } \\
\text { in mil USD }\end{array}$ & $\begin{array}{l}\text { Net Income (mil } \\
\text { USD) for 2013 }\end{array}$ \\
\hline First Bank of Nigeria PLC & 24,158 & 3,170 & 428 \\
\hline Zenith Bank Plc & 20,252 & 4,925 & 614 \\
\hline $\begin{array}{l}\text { United Bank for Africa } \\
\text { Plc }\end{array}$ & 17,025 & 1,629 & 300 \\
\hline Guaranty Trust Bank Plc & 13,549 & 5,445 & 580 \\
\hline Access Bank Plc & 11,826 & 1,389 & 234 \\
\hline Diamond Bank Plc & 9,786 & 579 & 184 \\
\hline Ecobank Nigeria PLC & 9,412 & 174 & 75 \\
\hline Skye Bank Plc & 7,195 & 276 & 103 \\
\hline Fidelity Bank PIc & 6,967 & 362 & 50 \\
\hline Union Bank of Nigeria Plc & 6,461 & 1,016 & 25 \\
\hline $\begin{array}{l}\text { First City Monument } \\
\text { Bank Plc }\end{array}$ & 6,435 & 510 & 103 \\
\hline Stanbic IBTC Bank PIc & 4,672 & 1,422 & 65 \\
\hline Sterling Bank Plc & 4,561 & 310 & 53 \\
\hline Unity Bank Plc & 2,375 & 120 & 15 \\
\hline Wema Bank Plc & 2,132 & 235 & 13 \\
\hline
\end{tabular}




\begin{tabular}{|l|l|l|l|l|l|l|}
\hline \multicolumn{6}{|l}{ Table 2: Descriptive Statistics relating to variables used in the Study, Early Adopters } \\
\hline & Pre IFRS Adoption & \multicolumn{4}{l|}{ Post IFRS Adoption } \\
\hline & Mean & Median & Std. Deviation & Mean & Median & Std. Deviation \\
\hline$\Delta$ NI & 0.010 & 0.012 & 0.006 & 0.005 & 0.003 & 0.014 \\
\hline$\Delta$ CF & 0.054 & 0.145 & 0.238 & -0.029 & 0.012 & 0.303 \\
\hline SIZE & 12.425 & 12.425 & 0.861 & 12.493 & 12.579 & 0.767 \\
\hline GROWTH & 0.618 & 0.613 & 0.331 & 0.257 & 0.202 & 0.327 \\
\hline EISSUE & 0.402 & 0.402 & 0.566 & 0.142 & 0.020 & 0.185 \\
\hline LEV & 7.378 & 7.479 & 2.457 & 6.562 & 6.352 & 2.438 \\
\hline DISSUE & 0.741 & 0.606 & 0.535 & 0.218 & 0.176 & 0.313 \\
\hline TURN & 0.095 & 0.101 & 0.018 & 0.114 & 0.113 & 0.021 \\
\hline CF & 0.163 & 0.163 & 0.137 & 0.007 & 0.028 & 0.154 \\
\hline CLOSE & 0.456 & 0.456 & 0.197 & 0.345 & 0.317 & 0.163 \\
\hline LLPR & 0.012 & 0.009 & 0.010 & 0.019 & 0.017 & 0.015 \\
\hline EBT & 0.033 & 0.033 & 0.009 & 0.031 & 0.026 & 0.016 \\
\hline LnTA & 13.569 & 13.693 & 0.670 & 14.351 & 14.372 & 0.460 \\
\hline CFEER & 0.025 & 0.025 & 0.006 & 0.019 & 0.019 & 0.005 \\
\hline
\end{tabular}

\begin{tabular}{|l|l|l|l|l|l|l|}
\hline \multicolumn{6}{|l|}{ Table 3: Descriptive Statistics relating to variables used in the Study, Late Adopters } \\
\hline & Pre IFRS Adoption & \multicolumn{4}{l|}{ Post IFRS Adoption } \\
\hline$\Delta$ NI & Mean & Median & Std. Deviation & Mean & Median & Std. Deviation \\
\hline$\Delta$ CF & 0.003 & 0.001 & 0.058 & 0.009 & 0.003 & 0.037 \\
\hline SIZE & -0.030 & 0.0156 & 0.242 & 0.022 & 0.032 & 0.107 \\
\hline GROWTH & 10.576 & 11.037 & 1.754 & 10.834 & 11.131 & 1.609 \\
\hline EISSUE & 0.238 & 0.213 & 0.429 & 0.259 & 0.257 & 0.188 \\
\hline LEV & 0.228 & 0.002 & 0.558 & 0.111 & 0 & 0.450 \\
\hline DISSUE & 7.418 & 5.430 & 7.939 & 15.965 & 7.074 & 39.223 \\
\hline TURN & 0.294 & 0.174 & 0.413 & 0.179 & 0.150 & 0.151 \\
\hline CF & 0.127 & 0.122 & 0.031 & 0.121 & 0.119 & 0.011 \\
\hline CLOSE & 0.001 & 0.019 & 0.144 & 0.036 & 0.034 & 0.072 \\
\hline LLPR & 0.297 & 0.231 & 0.157 & 0.195 & 0.160 & 0.124 \\
\hline EBT & 0.044 & 0.031 & 0.116 & 0.028 & 0.024 & 0.026 \\
\hline LnTA & 0.015 & 0.026 & 0.045 & 0.022 & 0.025 & 0.015 \\
\hline CFEER & 12.596 & 13.108 & 1.609 & 13.325 & 13.723 & 1.242 \\
\hline
\end{tabular}


Table 4: Regression analysis of stock return around IFRS announcement period

We test market reaction to the announcement of mandatory IFRS using the Fama and French four factor model. The excess annual return around the announcement is date is regressed against book to market ratio and firm size. The market return variable was not included because it has already been accounted for by the excess annual return. Sample used in this study excluded early adopters. This is because early adopters had already adopted IFRS before the announcement period hence their stock price would not be affected by the proposed policy. Abnormal returns $(\alpha)$ represent the constant term generated from the regression.

\begin{tabular}{|l|l|l|l|l|}
\hline & Coefficient & Standards error & t ratio & P value \\
\hline Abnormal returns $(\alpha)$ & -0.598 & 0.293 & -2.04 & 0.081 \\
\hline Book to market ratio & -0.046 & 0.117 & -0.39 & 0.707 \\
\hline Firm Size & 0.005 & 0.026 & 0.2 & 0.849 \\
\hline & & & & \\
\hline Number of Observation & 10 & & & \\
\hline F statistic & 0.09 & & & \\
\hline Adjusted R Squared & 0.125 & & & \\
\hline p-value & 0.918 & & & \\
\hline
\end{tabular}

\section{Table 5: Regression analysis of stock return during the Adoption period}

We test market reaction to the adoption of IFRS by Nigerian banks using the Fama and French four factor model. The sample includes both early adopters and late adopters. This is because we focus on the actual period the firm adopts IFRS and not the take-off date for mandatory adoption. We pool the observations and regress excess return against the firm size and book to market ratio. The $\alpha$ is the constant term generated from the regression.

\begin{tabular}{|l|l|l|l|l|}
\hline & Coefficient & Standards error & $\mathrm{t}$ ratio & $\mathrm{P}$ value \\
\hline Abnormal returns $(\alpha)$ & 1.829 & 0.478 & 3.83 & 0.002 \\
\hline Book to market ratio & -0.037 & 0.056 & -0.66 & 0.521 \\
\hline Firm Size & -0.113 & 0.042 & -2.68 & 0.02 \\
\hline & & & & \\
\hline Number of Observation & 15 & & & \\
\hline R Squared & 0.307 & & & \\
\hline F statistic & 4.10 & & & \\
\hline p-value & 0.0441 & & & \\
\hline
\end{tabular}




\section{Table 6: Regression analysis of stock return post adoption period}

We test market reaction since the adoption of IFRS by Nigerian banks using Fama and French four factor model. Having observed the short term impact during the adoption phase, we test whether this impact continued into the medium term. The sample used includes both early and late adopters. Since some of the banks adopted IFRS earlier on, the number of observations across each bank may vary. We use weekly observation for this study so as to obtain more observations and to pick up micro changes in stock returns. The observations are pooled and we regress excess return against firm size and book to market ratio. The $\alpha$ represent the constant term generated from the regression.

\begin{tabular}{|l|l|l|l|l|}
\hline & Coefficient & Standards error & t ratio & P value \\
\hline Abnormal returns $(\alpha)$ & 0.026 & 0.014 & 1.855 & 0.064 \\
\hline Book to market ratio & -0.009 & 0.002 & -3.564 & 0.000 \\
\hline Firm Size & -0.002 & 0.001 & -1.470 & 0.142 \\
\hline & & & & \\
\hline Number of observation & 871 & & & \\
\hline R Squared & 0.12 & & & \\
\hline F Statistic & 6.476 & & & \\
\hline p-value & 0.002 & & & \\
\hline
\end{tabular}

Table 7: Comparing Earnings management Pre and Post IFRS Adoption

We study the variability of net income of firms before and after they adopt IFRS by dividing our sample into two; early adopters and late adopters. This distinction was initiated to identify if the two samples responded differently to IFRS. We model $\Delta$ NI using model 2 . We save the residuals and calculate the variance of this residual. This process is carried out separately for each of the sample. The residuals are estimated for pre adoption and post adoption periods.

\begin{tabular}{|l|l|l|}
\hline & Variability of $\Delta$ NI \\
\hline & Pre IFRS Adoption & Post IFRS Adoption \\
\hline Early adopters & 1.743 & 1.193 \\
\hline Late adopters & 0.003 & 0.000 \\
\hline
\end{tabular}




\section{Table 8: Comparing Earnings management Pre and Post IFRS adoption}

We study the ratio of the variability of change in Net income to change in cash flow pre and post IFRS adoption in order to test whether firms engage in earnings management. The metric we adopt here uses the residuals from a regression of $\triangle \mathrm{CF}$ against variables listed found in model 3. Then we run model 3 and estimate residuals for pre and post IFRS adoption for each of the samples. Having obtained the variance of residuals for $\triangle \mathrm{CF}$ pre and post IFRS adoption for each sample, we then matched and divided each period's $\Delta \mathrm{NI}$ variance by the corresponding $\triangle \mathrm{CF}$ variance to obtain the ratio. For early adopters, we divided the variance of $\Delta$ NI pre IFRS adoption by the variance of $\Delta C F$ pre IFRS adoption to obtain the pre-adoption ratio for early adopters.

\begin{tabular}{|l|l|l|}
\hline & \multicolumn{2}{|l|}{ Ratio of Variability of $\Delta \mathrm{NI}$ to Variability of $\Delta \mathrm{CF}$} \\
\hline & Pre IFRS Adoption & Post IFRS Adoption \\
\hline Early adopters & 0.00014325 & 0.003652282 \\
\hline Late adopters & 0.256130672 & 0.200759895 \\
\hline
\end{tabular}




\section{Table 9: Regression analysis of loan loss provision pre and post CBN reform}

The sample contain all banks, there is no distinction between early and late IFRS adopters. Owing to the non-uniform availability of data, some banks had more observations than others. For example, ECO bank had 8 observations while Wema bank had 5; hence the panel data is unbalanced. The major part of the CBN reform took place between 2009 and 2012, for simplicity we assume that the reform was enacted in 2011; REFORM variable takes a value of 1 for 2011 and onwards, or else 0 . We pooled all the observations and regressed them using model 4.

\begin{tabular}{|l|l|l|}
\hline & Coefficient & P-value \\
\hline constant & 0.154085 & 0.3018 \\
\hline EBT & 0.207203 & 0.496 \\
\hline IFRS & -0.00339285 & 0.8974 \\
\hline REFORM & -0.003849 & 0.9025 \\
\hline REFORM*EBT & -1.35918 & 0.0757 \\
\hline IFRS*REFORM*EBT & -0.544978 & 0.6106 \\
\hline LnTA & 0.0025187 & 0.7362 \\
\hline CFEER & -0.651856 & 0.3208 \\
\hline GDP GROWTH & -0.0196349 & 0.1093 \\
\hline DCROOS & 0.000129 & 0.9957 \\
\hline
\end{tabular}

